\title{
RUBIERA CANCELAS, CARLA. LA ESCLAVITUD FEMENINA EN LA ROMA ANTIGUA. FAMULAE, ANCILLAE ET SERUAE (COLECCIÓN DEMÉTER). OVIEDO: EDICIONES TRABE, 2014. 302 p. ISBN: 978-84-8053-777-3
}

Filipe N. Silva ${ }^{1}$

Escrevendo em uma época em que a antiga escravidão por dívidas (nexum) era inexistente, o jurista Marciano, em uma conhecida passagem registrada no Digesto (D. I.5.5), elucidava que seriam escravizados os indivíduos capturados dos inimigos, ou aqueles "(...) nascidos de nossas escravas" (ex ancillis nostris nascuntur). Ao lado da guerra, a reprodução biológica era reconhecida pelos antigos como critério de escravização. Em âmbito romano, onde a transmissão da condição servil foi pensada sob um padrão matrilinear (Patterson, 1982: 139), tal designação conduz à constatação de que homens e mulheres teriam experimentado a escravidão de maneiras distintas. Essa diferença, contudo, não se restringe apenas ao o tema da reprodução biológica.

Partindo da premissa de que as escravas romanas, por seu status social e também por uma questão de gênero, estariam sob um duplo padrão de submissão, o livro La esclavitud femenina en la Roma Antigua (2014), da estudiosa espanhola Carla Rubiera Cancelas, apresenta um retrato abrangente da experiência feminina da escravidão na Roma Antiga. Constituído por um repertório documental formado por textos literários e jurídicos, além de inscrições funerárias e representações iconográficas, o estudo de Rubiera Cancelas está dividido em cinco capítulos principais. No primeiro capítulo, a autora reconstitui o percurso historiográfico concernente à História das Mulheres Romanas e constata, apesar de algumas exceções, um interesse tardio pelo tema da escravidão romana com ênfase na experiência das mulheres.

Reivindicando uma postura crítica em relação às fontes antigas, o segundo capítulo, intitulado El uso de las fuentes, salienta que os textos literários e jurídicos sobre a escravidão antiga, quase sempre produzidos por homens de pleno direito, representariam a opinião de indivíduos imbuídos de uma perspectiva escravista, misógina e favorável à dominação (p.47-48). A epigrafia, neste caso, é considerada uma alternativa profícua em direção a um testemunho histórico menos tendencioso acerca das mulheres escravizadas.

${ }^{1}$ Doutorando em História Cultural, IFCH/Unicamp. E-mail: filipe.hadrian@gmail.com Heródoto, Unifesp, Guarulhos, v.4, n.1 - 2019.1. p. 423-424

DOI: 10.34024/herodoto.2019.v4.10130 
O terceiro capítulo trata da construção textual, jurídica e iconográfica das escravas e dos escravos romanos. Após analisar as imagens dos escravos retratados como bárbaros nos troféus e monumentos romanos, a autora reitera a conhecida condição de outsider atribuída aos escravos nessa sociedade. Em consonância com as teorias pós-coloniais e de gênero e sob a influência direta do ensaio Can the subaltern speak?, de Gayatri Spivak, Carla Rubiera Cancelas (2014. p.115-117) reconhece a subalternidade das escravas romanas em seu profundo silenciamento nas fontes textuais antigas.

O quotidiano laboral das escravas romanas é o tema do quarto capítulo do livro, intitulado Trabajadoras esclavas en la ciudad de Roma. A partir dos testemunhos epigráficos, Rubiera Cancelas (2014) desconsidera a conhecida hipótese do confinamento doméstico feminino e descreve as múltiplas ocupações das seruae e ancillae em âmbito citadino. Além das atividades têxteis, a medicina, o ensino, a amamentação, a prostituição, a dança, as artes e espetáculos públicos também seriam espaços onde a autora evidencia constante atuação feminina.

O tema da reprodução biológica da escravidão, por fim, é tratado no quinto capítulo do livro. Embora constate, por um lado, um repertório literário e jurídico que circunscreve às mulheres o papel de "(..) mães a serviço de um sistema econômico e social que as utiliza" (Rubiera Cancelas, 2014: 249), por outro lado, a autora também destaca, novamente a partir da epigrafia, os laços de parentesco construídos por essas mulheres com o intuito de superar a eventual morte social instalada pela escravidão.

Munido de uma consistente pesquisa histórica e arqueológica, o livro de Rubiera Cancelas (2014) demonstra como a História da Antiguidade pode reagir de maneira satisfatória às demandas sociais contemporâneas. Ao evidenciar a arbitrariedade dos julgamentos morais sobre as mulheres romanas, mas também por apontar o silenciamento das escravas nas fontes antigas, a autora nos convida à reflexão permanente sobre as relações entre poder, saber e exclusão social. $\mathrm{O}$ uso das teorias de gênero, conforme demonstrado em La esclavitud femenina em la Roma Antigua, convida-nos a repensar os regimes de escravidão, antigos ou modernos, sob uma nova e proveitosa perspectiva.

Referências bibliográficas

PATTERSON, Orlando. Slavery and social death. A comparative study. Harvard: University Press, 1982. 